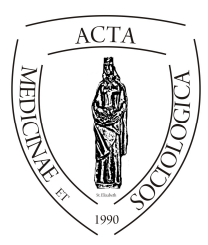

\title{
A családi háttér szerepe az egészségmagatartásban
}

\author{
Horváth Cintia
}

Szociális munkás BA hallgató, Debreceni Egyetem Egészségügyi Kar, 4400 Nyíregyháza, Sóstói út 2-4.

\begin{tabular}{|c|c|}
\hline INFO & ABSTRACT \\
\hline $\begin{array}{l}\text { Cintia Horváth } \\
\text { horvatcintia97@gmail.com }\end{array}$ & \multirow[b]{2}{*}{$\begin{array}{l}\text { The role of family background in health behaviour. The } \\
\text { question I am looking for is how the family background } \\
\text { influences the health of young people. To this end, I present } \\
\text { the family background of the young people ( } 890 \text { persons) who } \\
\text { are in the database of the research of the background of the } \\
\text { risk behavior of children and young people in the social } \\
\text { periphery (KAB-KT-16-25568), focusing solely on the } \\
\text { quality characteristics of parenting. I also describe the risk } \\
\text { behavior of young people in research, segregated or } \\
\text { specialized careers. I opted for this method instead of taking } \\
\text { into account the self-reported risk behavior of the interviewer, } \\
\text { because experience shows that the circle of friends is socially } \\
\text { condemnable, punishable, openly speaking, and we get a } \\
\text { better picture of reality. It can be assumed that if the family's } \\
\text { network is weakened, damaged, it has the potential to risk the } \\
\text { health of young passionate passions. All in all, I examine the } \\
\text { qualitative characteristics of the relationship between } \\
\text { children and young people in the periphery (quality of mee- } \\
\text { ting with parents, parental monitoring, trustful / supportive } \\
\text { relationship) and how these characteristics affect health } \\
\text { behavior, assuming that the typical health behavior of friendly } \\
\text { relationships is significant has an impact on the health of the } \\
\text { respondent. I examine the empirical, statistical correlations of } \\
\text { the question (chi-squared test) along these variables. }\end{array}$} \\
\hline $\begin{array}{l}\text { Keywords } \\
\text { role of family, } \\
\text { parent-child relationship, } \\
\text { parent information, } \\
\text { parent support, } \\
\text { risk management }\end{array}$ & \\
\hline $\begin{array}{l}\text { Kulcsszavak } \\
\text { család szerepe, } \\
\text { szülő-gyerek kapcsolat, } \\
\text { szülő informáltsága, } \\
\text { szülő támogatása, } \\
\text { rizikómagatartás }\end{array}$ & $\begin{array}{l}\text { Absztrakt. Arra a kérdésre keresem a választ, hogy a családi } \\
\text { háttér milyen befolyásoló erővel bír a fiatalok egészségmaga- } \\
\text { tartására. Ennek érdekében bemutatom a társadalmi periférián } \\
\text { élő gyermekek és fiatalok rizikómagatartásának hátterére irá- } \\
\text { nyuló megyei kutatás (KAB-KT-16-25568) adatbázisába ke- } \\
\text { rült fiatalok ( } 890 \text { fö) családi hátterét, jelen esetben kizárólag a } \\
\text { szülői kapcsolat minőségi jellemzőire koncentrálva. Ismerte- } \\
\text { tem továbbá a kutatásba bevont, szegregátumban vagy szakel- } \\
\text { látásban élő fiatalok baráti körének rizikómagatartását. Azért } \\
\text { ezt a módszert választottam a megkérdezett önbevallott rizikó- } \\
\text { magatartásának figyelembevétele helyett, mert a tapasztalatok }\end{array}$ \\
\hline
\end{tabular}


szerint a baráti kör társadalmilag elítélhető, büntethető szokásairól, nyíltabban beszélnek, valósághoz jobban illeszkedő képet kapunk. Feltételezhető, hogy amennyiben a család kapcsolati hálója gyengül, sérül, megvan annak a veszélye, hogy a fiatal káros szenvedélyekkel kockáztatja az egészségét. Összességében tehát a periférián élő gyerekek-fiatalok és szüleik kapcsolatának minőségi jellemzőit (szülőkkel való megbeszélés minősége, szülői monitoring, bizalomteli/támogató kapcsolat) vizsgálom, és azt, hogy ezek jellemzők hogyan hatnak az egészségmagatartásra, amennyiben feltételezzük, hogy a baráti kapcsolatok jellemző egészségmagatartása jelentős hatást gyakorol a megkérdezett egészségmagatartására. Ezen változók mentén vizsgálom a kérdés empirikus, statisztikai összefüggéseit (khí2-próba).

Ez a tanulmány a Magyar Tudomány Ünnepén („Ember a társadalomban és az egészségügyben” - 2017. 11. 29., Debreceni Egyetem Egészségügyi Kar) elhangzott előadás alapján készült.

\section{Bevezetés}

Bemutatom a társadalmi periférián élő gyermekek és fiatalok droghasználati szokások feltárására irányuló nagymintás kutatás eredményeit. Továbbá ismertetem az adatbázisba került fiatalok családi hátterét, a szülői kapcsolat minőségét és ezek hatását az egészségmagatartásra. A család fontos védőhálóként is funkcionál az egészségromboló magatartással szemben. Feltételezhető, hogy ha a család kapcsolati lánca gyengül, sérül, megvan annak a veszélye, hogy a fiatal káros szenvedélyekkel kockáztatja az egészségét. A rizikómagatartás különböző aspektusai közül a dohányzás, alkoholés drogfogyasztás kockázati tényezők összefüggéseit ismertetem, amely elkerülhető és a korai halálozáshoz vezethet.

A kutatás két csoportra oszlik, 14-18 és 19-24 évesekre. A minta nagyobbik részét a telepszerü körülmények között élő fiatalok adták, akik életvitelszerüen a település szegregátumaiban, illetve szegregációval veszélyeztetett területen tudtunk lekérdezni. A minta kisebbik részét pedig a szakellátásban nevelkedett gyermekek és fiatalok adták, akiket nevelőszülőknél, lakásotthonokban és gyermekotthonokban értünk el. Összesen 890 fő vett részt az adatbázis lekérdezésében (Fábián, Szoboszlai és Hüse, 2017).

Nemzetközi és hazai nagymintás kutatások (ESPAD, HBSC, Magyar Ifjúság) mutatják be, hogy a fiatalok körében még mindig jelentősen elterjedt a dohányzás, alkohol- és a kábítószerfogyasztás.

HBSC vizsgálatok rávilágítanak, hogy Magyarországon is egyre korábbi életkorra tehető a szerfogyasztás. Továbbá a kutatás beszámol a fiatalok nagy ivásáról, amely már meghaladja a felnőttek alkoholfogyasztását. Iskolatípusok és iskolai végzettségek között látható különbség a gimnáziumban tanuló fiatalok közül kevesebben fogyasztanak alkoholt, mint a szakiskolás tanulók. Az ESPAD kutatók is rávilágítanak arra, 
hogy a 90-es évektől erőteljes növekedés látható a drogfogyasztásban. A legelterjedtebb tudatmódosítószer továbbra is a marihuána, pszichoaktív szerek, mint például a szintetikus kannabinoidok csoportja (Horváth, 2017).

A tanulmány felépítését tekintve tartalmaz elméleti, valamint empirikus részt is. A tisztázandó fogalmak meghatározása után bemutatom a kapott adatokat és azok feldolgozását.

\section{Szakirodalmi áttekintés}

A család az elsődleges szociális közeg, ahol a szocializáció és a személyiségfejlődés elkezdődik, hiányát egyetlen családpótló ellátással nem lehet helyettesíteni. Ebben a közegben sajátítjuk el, hogy milyen normáknak kell eleget tenni, hogyan legyünk a társadalom hasznos tagjai. Az egyént egész élete során végigkíséri az a hatás, amely a jólétére, testilelki-mentális egészségére kihat. Ha a család diszfunkcionálisan müködik, akkor azt „mérgező” családnak tekintjük, a családban az érzelmi kapcsolatok elmaradnak vagy erősen deformálttá válnak. Jellemző továbbá az eltorzult kommunikáció. A szülői attitüd hatást gyakorol az egyénre, ez pedig szoros összefüggésben van az egészségmagatartással (Pénzes és mtsai., 2007).

A rizikómagatartás magába foglalja azokat a szokásokat, amelyek erőssége vagy tartóssága miatt következik be az egészségkárosodás. Az egyén rizikómagatartását nagymértékben befolyásolja a szocializáció, pszichoszociális megbetegedésekre való hajlamosság vagy a kortársak magatartása. A kortársak nagy hatást gyakorolnak az egyénre, mivel a fiatalok idejük lényeges részét a kortárscsoportokkal töltik. Még akkor is nagy hatással van a fiatalra a kortárscsoport, ha a szülő és a gyermek között bensőséges kapcsolat áll fent. A családtagok különbözö funkciókat látnak el, a családban kialakult szerepek és az ezekben történő változások jelentősen hatnak a fiatal későbbi életminőségére (Hüse, Huszti és Takács, 2016).

A vizsgálatok azt mutatják, hogy a szülő gyakorolja a legnagyobb hatást a gyermek droghasználatában. A szülő informáltsága, támogatása befolyásolhatja a tudatmódosítószer kipróbálásában és fogyasztásában is egyaránt, minél jobb a szülö-gyerek bizalmi viszonya, annál kevesebb az esély arra, hogy kipróbálja a különféle tudatmódosítószer egyikét. Az elsődleges szocializációs tér objektív és szubjektív tényezői rávilágítanak a törvényszerúen kapható és a tilosan beszerezhető kábítószer használatára. Az első szubjektív szempont a szülö- gyerek közötti bizalmiviszony minősége, a fiatal kategóriába sorolja, hogy az anyjával és apjával mennyire könnyen tudnak kommunikálni. Második tényező a szülő tájékozódása a fiatallal kapcsolatos dolgokban. Harmadik összetevő a szülő nevelési módszere, szellemi beállítottsága, amely hatást gyakorol a fiatalra. Tehát a szerfogyasztást jelentősen befolyásolja, ha az apa dezinformált az esti és iskola utáni szabadszünetről és ha az apa büntető nevelési technikát alkalmazza (Murányi, Horváth és Hüse, 2008).

Ellion és mtsai. a kutatások során rámutatnak, hogy a fiatalok deviáns viselkedését a kortársakkal kialakuló közeli kapcsolat elözte meg.

Needle és intai, kutatások szerint a barátok szerhasználata figyelmeztet és jelzi a válaszadó fiatal kábítószerhasználatát. 
Gerevich és Bácskai kutatásukban az általános és a középiskolás fiatal a célcsoport és megfigyelhetö, hogy a rizikómagatartás szoros összefüggésben áll a kortárs kapcsolatok erősségével.

Rácz József vizsgálatai bemutatják, hogy a kábítószerhasználat kialakulásában legfőbb veszélyeztető szerepet a deviáns társcsoport tölti be (Rácz J., 1995).

A fiatalok egészségmagatartása hatással van a jelenlegi és a jövőbeli egészségükre. Az egészségmagatartás két aspektusát ismerjük, ezek a pozitív és negatív. A negatív tényezők alatt azokat a szokásokat értjük, amelyek erőssége vagy tartóssága miatt egészségkárosodás következik be, ezt nevezzük rizikómagatartásnak (Bauer és Komássy, 2008).

\section{Eredmények}

A családi szerkezeten belül négy szereplőt vizsgáltam a megbeszélés minőség esetében, édesapa, nevelőapa, édesanya, nevelőanya. A szakellátásban nevelkedett fiatalok esetében pedig valamelyik gondozójával való megbeszélés intenzitását mérem fel. A kérdés - „milyen könnyen tudod megbeszélni a téged nagyon foglalkoztató, vagy zavaró dolgokat?” - nem a társalgás „könnyüségét” vagy „nehézségét” vizsgálja és nem a problémára irányul, hanem a gondok átadására, megértésére és érzelmi feldolgozására.

A családi kapcsolatok tartalmát tekintve megfigyeltük, hogy a fiatalok milyen könnyen tudják megbeszélni az őket foglalkoztató kérdéseket, vagy zavaró tényezőket a családtagokkal. Feltételezhetjük, hogy a fiatalok azt a családtagot tekintik empatikusabbnak, akikkel a problémákat könnyen meg tudják beszélni. Akikkel pedig nehezen tudják megbeszélni, őket nem tekintik empatikus személynek. Az édesapával való megbeszélés minőségét tekintve láthatjuk, hogy a nehezen kategóriában 23\%-a azok a fiatalok aránya, akiknek „,néhány” barátja iszik szeszesitalt. Ez az arány a nagyon könnyen kategóriában közel 20\%. A lerészegedő barátokat megvizsgálva láthatjuk, hogy ha a gyermek úgy érzi, hogy a szülővel nehezen ért szót, azok fiatalok 30\%-nak van „néhány” barátja, aki hetente egyszer vagy többször lesz részeg. Ez az arány a nagyon könnyen kategóriában közel 15\%. Továbbá elmondható, hogy a megbeszélés minősége nem mutat összefüggést a rizikós baráti kapcsolatokkal. (1. ábra)

Nevelőapát tekintve a nehezen kategóriában a barátok „,néhánya” és „többsége” kategóriában 22\%-nak a barátja fogyaszt alkoholt. Nagyon könnyen kategóriában pedig ez az arány alacsonyabb, közel 17\% (1. ábra). 
Édesapával való megbeszélés minősége Hány barátod iszik alkoholt?

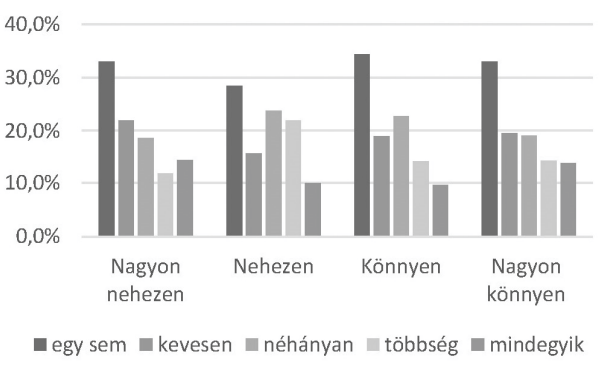

Nevelőapával való megbeszélés minősége

Hány barátod iszik alkoholt?

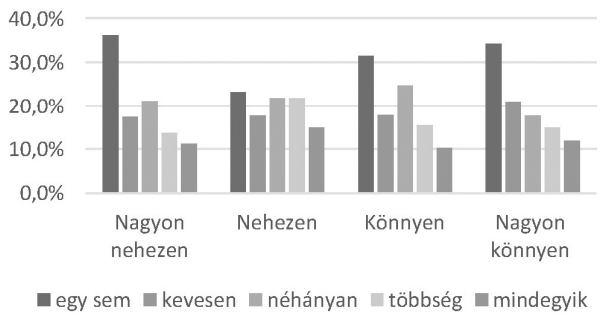

Édesapával való megbeszélés minősége Hány barátod lesz részeg hetente egyszer vagy többször?

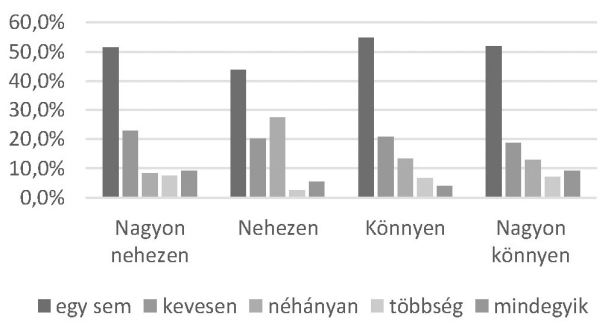

Nevelőapával való megbeszélés minősége

Hány barátod lesz részeg hetente egyszer vagy többször?

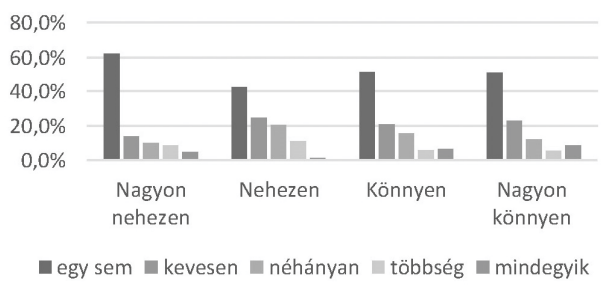

1. ábra. Milyen könnyen tudják megbeszélni a gondokat az édesapával/nevelőapával?

Édesanyával való megbeszélés a nagyon nehezen minősített kategóriában jól látható, hogy a megkérdezett fiatal baráti társaságból „mindegyik barát” kategóriában 18\% fogyaszt alkoholt. Míg akik nagyon könnyen megbeszélik a gondokat az édesanyával azok a „mindegyik” barátot jelzett kategória csupán 3,6\%. Ennek tekintetében a lerészegedő barát aránya a nagyon nehezen kategóriában 12,1\%-nak „mindegyik” barátja fogyaszt alkoholt. Míg ezt figyelve a nagyon könnyen kategóriában ez csupán 1,8\%. Édesanyával való megbeszélés minősége sokkal inkább befolyásolja a rizikós baráti kapcsolatokat, mint az édesapával való megbeszélés minősége (1. ábra).

A nevelőanyával kapcsolatban szintén elmondható (mint az anyánál), hogy a nagyon nehezen kategóriában a megkérdezett fiatal bevallása alapján a barátainak a „többsége”, „mindegyike” 18,8\% fogyaszt alkoholt. Míg akik nagyon könnyen tudnak szót érteni a nevelőanyával, azok csak 2,5\% vallotta, hogy „mindegyik” barátja iszik alkoholt. A lerészegedések arányát tekintve a nehezen kategóriában látható, hogy 23,1\% vallotta, hogy „néhány” barátja fogyaszt alkoholt. Ez az érték a nagyon könnyen kategóriában csak $13 \%$. Azt persze nem tudhatjuk, hogy az anyai megbeszélés nehézségéből vagy a gyerek rossz társaságából fakad a sok konfliktus az anyával (1. ábra). 
Édesanyával való megbeszélés minősége

Hány barátod iszik alkoholt?

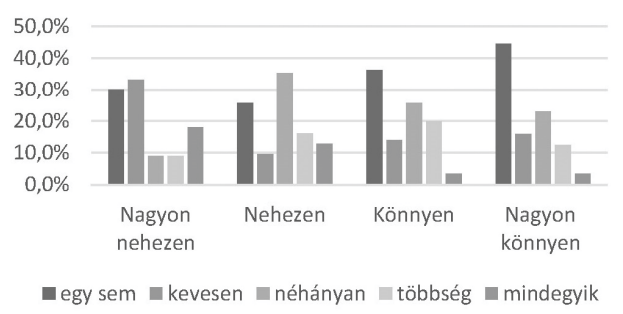

Nevelőanyával való megbeszélés minősége

Hány barátod iszik alkoholt?

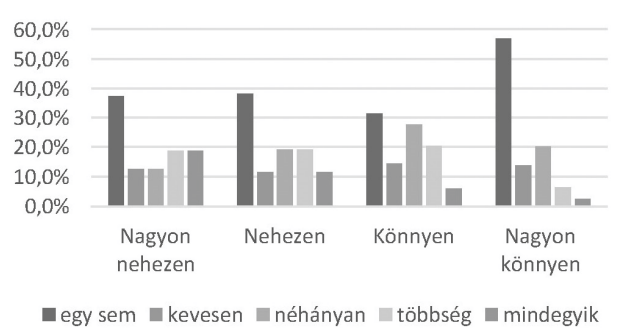

Édesanyával való megbeszélés minősége

Hány barátod lesz részeg hetente egyszer vagy többször?

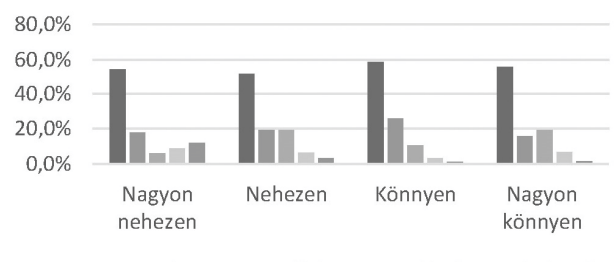

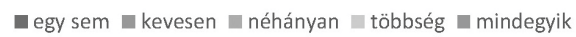

Nevelőanyával való megbeszélés
minősége

Hány barátod lesz részeg hetente egyszer vagy többször?

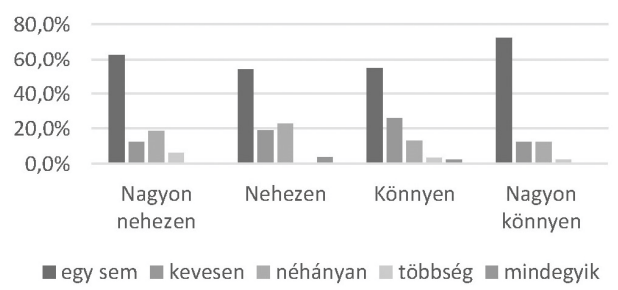

2. ábra. Milyen könnyen tudják megbeszélni a gondokat az édesanyával/nevelőanyával?

A szakellátásban nevelkedett fiatalokra térnék most rá, a valamelyik gondozóval való megbeszélés minőségét tekintve igencsak befolyásolja a rizikós baráti kapcsolatot. A nagyon nehezen minősített megbeszélés kategóriájában látható, hogy 15,7\%-nak „mindegyik” barátja fogyaszt alkoholt. Akik nehezen tudnak szót érteni a gondozóval, azok 27,5\%-a mondta, hogy barátai „többsége” fogyaszt alkoholt. Míg akik nagyon könnyen szót értenek azok csupán 5,7\%-nak „mindegyik” barátja fogyaszt alkoholt. Ennek tekintetében a következő diagramon (2. diagram) a barátok lerészegedését nézve, látható, hogy akik nehezen tudják megbeszélni a problémákat 38\%-nak a „mindegyik” barátja részeg lesz hetente egyszer vagy többször, Míg ezt megfigyelve a nagyon könnyen kategóriában csupán 4,5\%. 


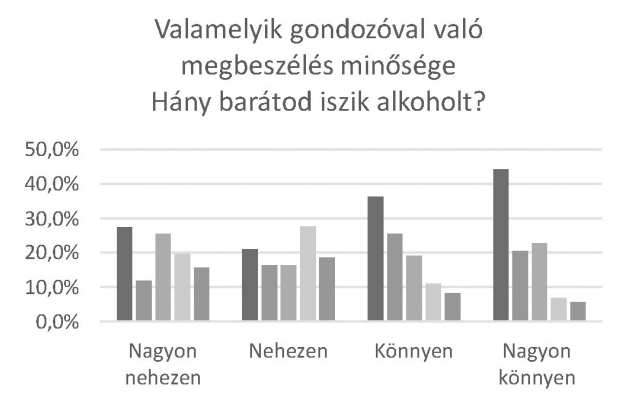

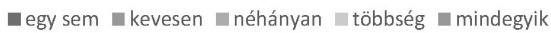
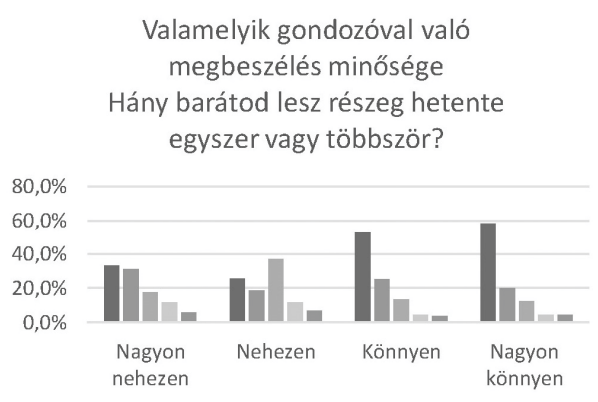

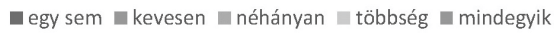

3. ábra. Milyen könnyen tudják megbeszélni a gondokat a (valamelyik) gondozóval?

A 3. diagramon a gyermek által becsült anya és apa informáltságát vetettem össze. Látható, hogy a megkérdezett fiatalok az anyai figyelmet intenzívebbnek érzik/vélik, mint az apáét. Tehát megállapíthatjuk, hogy az anyákkal bensőségesebb a kapcsolat, ez nagyjából 10\%-kal magasabb értéket mutat az apai monitoringtól.

\section{Szülő átlagos informáltsága}

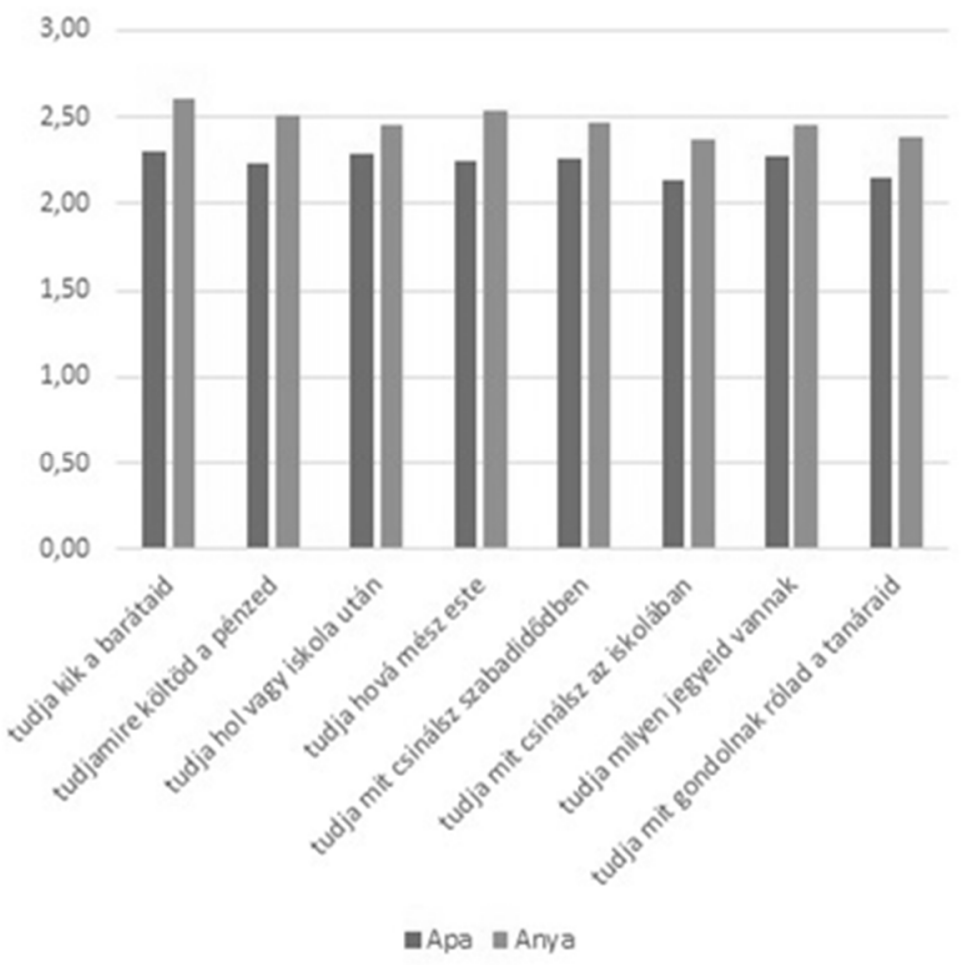

4. ábra. Szülő átlagos informáltsága. 
Nézzük meg, hogy az anyai monitoring mennyire befolyásolja a fiatalt a káros szenvedélyek kipróbálásában. Tudja kik a barátaid, tudja mire költöd a pénzed, tudja hol vagy iskola után, tudja hová mész este, tudja mit csinálsz szabadidődben, tudja mit csinálsz az iskolában, tudja milyenek a jegyeid, tudja mit gondolnak rólad a tanárok. Az előbb bemutatott 10 kérdést összegeztem és látható, hogy a fiatalok értékelése szerint, ha az anya semmit nem tud velük kapcsolatba akkor 28,8\%-nak a baráti „,többsége" cigarettázik. A sokat tudnak kategóriában pedig több mint 41,5\%-ra növekedik a megkérdezett fiatal baráti „többsége” akik dohányoznak. Alkoholt tekintve ugyanez látható, semmit tud kategóriában közel 30\%-nak a baráti „többség” fogyaszt alkoholt, míg ha az anya sokat tud a gyermek belátása szerint azoknak 37,4\%-nak a baráti „,többsége” fogyaszt alkoholt. A barátok részegségét tekintve a semmit tud kategóriában a közel 40\%-nak a barátok ,többsége” lesz részeg hetente egyszer vagy többször, míg a sokat tud kategóriában 35\%-nak a barátok „többsége” lesz részeg hetente egyszer vagy többször. A kábítószer használatnál is jól látható, hogy azoknak a fiataloknak a baráti „többségük” használ kábítószert, ahol az anyai monitoring gyenge, ez közel $40 \%$ barátot jelent. Viszont sokat tud kategóriában 33\%-nak a barátjának a „,öbbsége” használ kábítószert. (5. ábra).
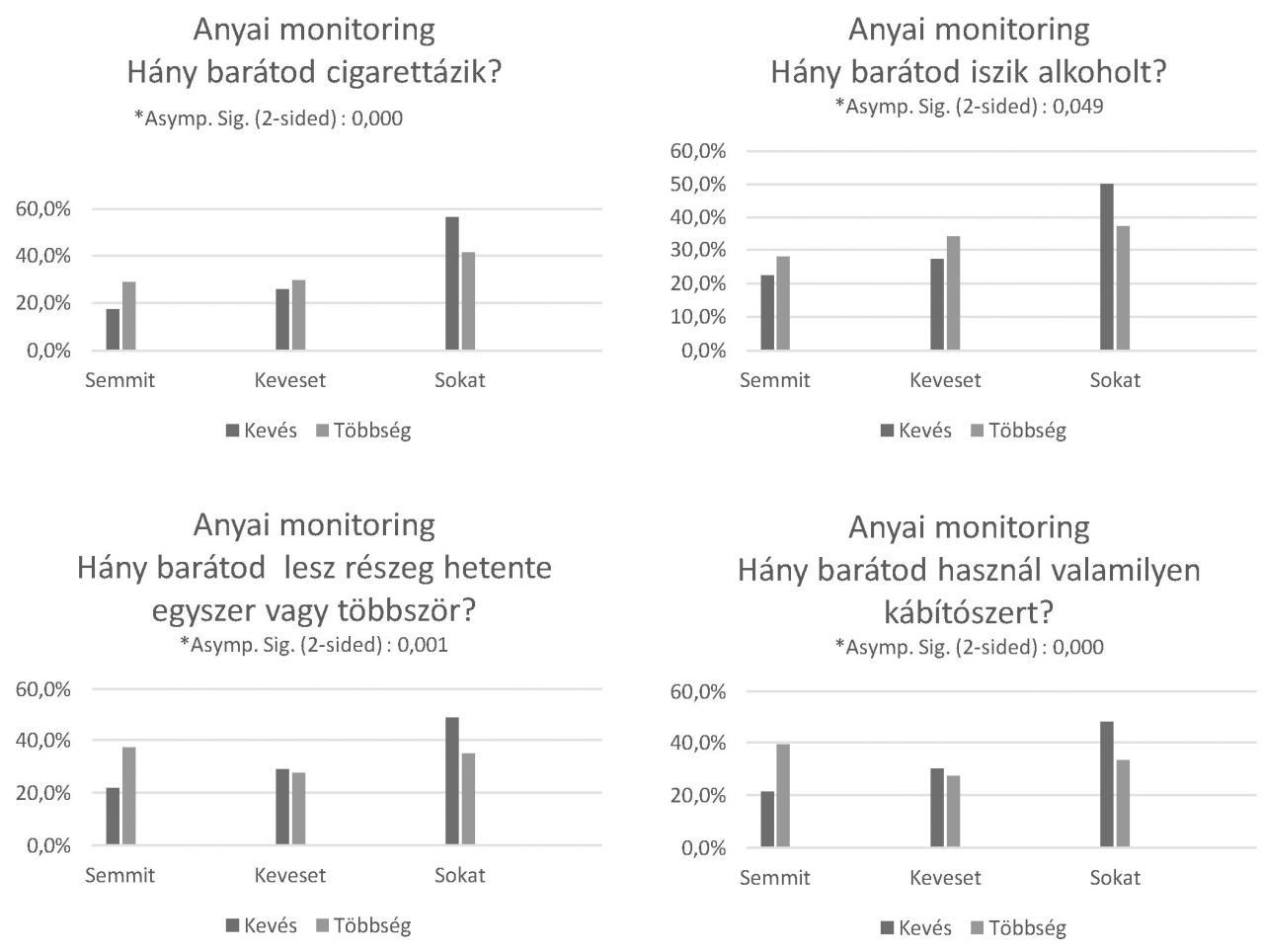

5. ábra. Anyai monitoring. 
Az apai monitoringot tekintve a semmit tud kategóriában a válaszadó fiatalok baráti „többsége” dohányzik ez 41,6\%-ot jelent. Ha pedig a válaszadó fiatal úgy érzi, hogy az apa sokat tud róla, akkor ez az arány $26,9 \%$. Az alkohol fogyasztást illetően, ha a fiatal azt gondolja, hogy az édesapja semmit sem tud róla, akkor a baráti „többségének" a 40,4\%-a fogyaszt szeszesitalt és ez az érték a sokat tud kategóriában $25,3 \%$. A részegség a megkérdezett fiatalok baráti körében megfigyelhető, hogy 41,6\% lesz részeg hetente egyszer vagy többször, ha a válaszadó úgy érzi, hogy apja semmit nem tud róla. A „hány barátod használ valamilyen kábítószert” kérdésben, ha az apai monitoring gyenge, akkor a válaszadó barátainak a „többsége” közel 50\%-a használ kábítószert. Ha a fiatal úgy érzi, apja sokat tud róla, ebben a kategóriában a fiatalok baráti „,öbbsége”, azaz 22,6\% fogyaszt valamilyen drogot (6. ábra).
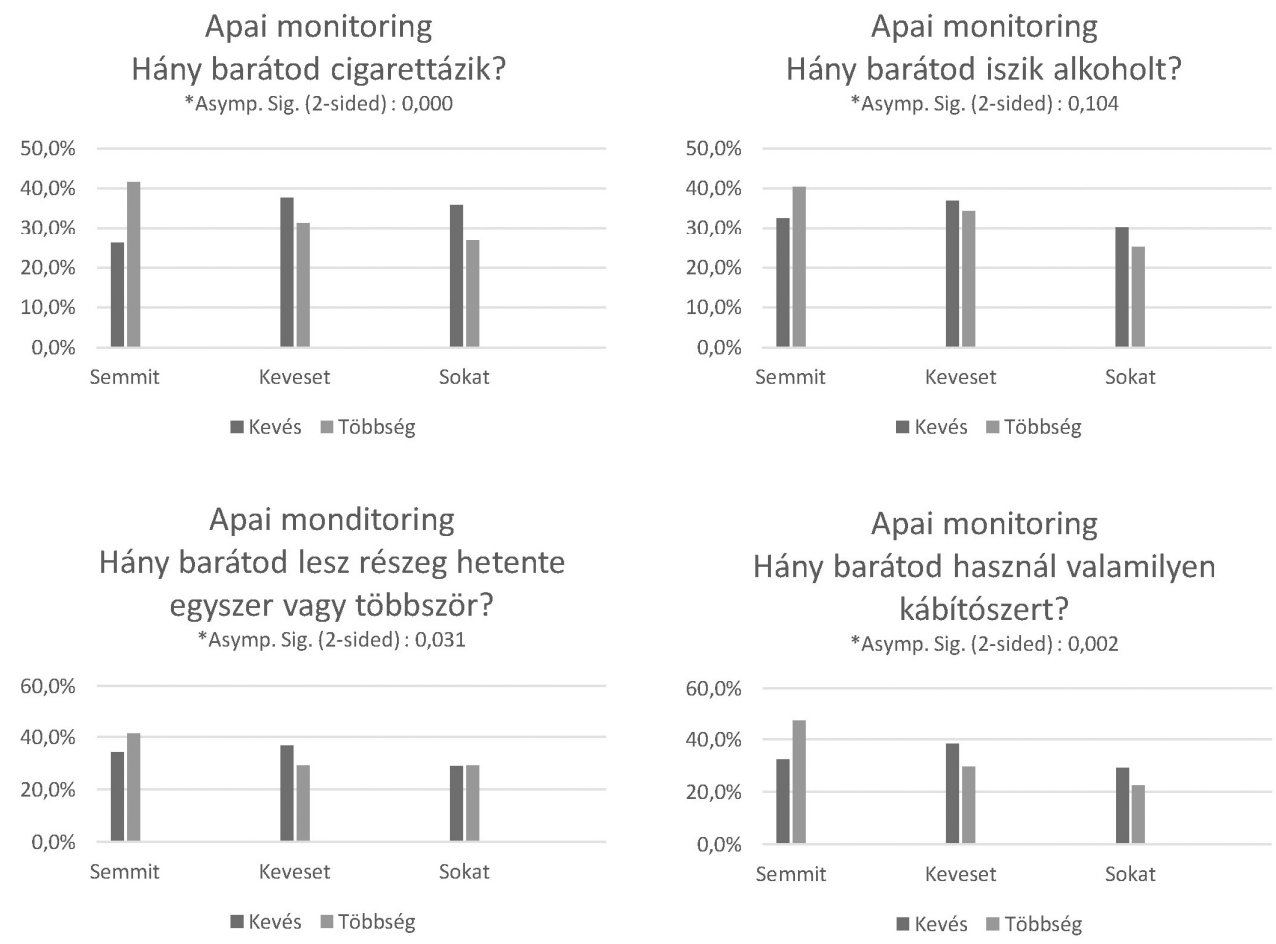

6. ábra. Apai monitoring.

A 10 kérdés a bizalom meglétéről tanúskodik, reprezentálják a szülői mentalitást. Milyen veled édesapád/édesanyád, segít, engedékeny, türelmes, megértő, szereti, ha önállóan döntesz, ellenőriz, gyerekként bánik veled, meg tud vigasztalni, bíztat a tanulásra vagy nem hiszi, hogy van értelme.

Az 1.táblázatban a szignifikáns értékek lettek kiemelve, jól látható a releváns öszszefüggés. Három kérdés kategóriát kiemelnék a „türelmes velem”, „meg tud vigasztalni, ha valami bánt” és a „biztat, hogy tanuljak rendesen” mind anyára és apára vo- 
natkoztatva is kijelenthető, hogy van összefüggés az egészségmagatartással, ha feltételezzük azt, hogy a barátok egészségkárosító szokásai befolyásolják a megkérdezett egészségét. A megkérdezett baráti társasága cigarettázik kategóriában az apai támogató kapcsolat az, amelyben több szignifikáns értéket láthatunk (amely erősebb befolyásoló erővel bír.)

A megkérdezett barátok tekintetében

\begin{tabular}{|c|c|c|c|c|c|c|c|c|}
\hline & \multicolumn{2}{|c|}{ Cigarettázik } & \multicolumn{2}{|c|}{$\begin{array}{l}\text { Alkoholt } \\
\text { iszik }\end{array}$} & \multicolumn{2}{|c|}{$\begin{array}{l}\text { Részeg lesz } \\
\text { hetente egy- } \\
\text { szer vagy } \\
\text { többször }\end{array}$} & \multicolumn{2}{|c|}{$\begin{array}{c}\text { Kábítószert } \\
\text { használ }\end{array}$} \\
\hline & Apa & Anya & Apa & Anya & Apa & Anya & Apa & Anya \\
\hline $\begin{array}{l}\text { Segít, ha szükségem van } \\
\text { rá }\end{array}$ & 0,10 & 0,21 & 0,00 & 0,00 & 0,00 & 0,00 & 0,00 & 0,00 \\
\hline $\begin{array}{l}\text { Engedi, hogy azt te- } \\
\text { gyem, amire szükségem } \\
\text { van }\end{array}$ & 0,05 & 0,52 & 0,02 & 0,28 & 0,01 & 0,83 & 0,14 & 0,70 \\
\hline Türelmes velem & 0,00 & 0,40 & 0,00 & 0,01 & 0,00 & 0,01 & 0,00 & 0,00 \\
\hline $\begin{array}{l}\text { Megérti a problémáimat, } \\
\text { gondjaimat }\end{array}$ & 0,01 & 0,22 & 0,00 & 0,05 & 0,00 & 0,12 & 0,00 & 0,03 \\
\hline $\begin{array}{l}\text { Szereti, ha én döntök a } \\
\text { dolgaimban }\end{array}$ & 0,08 & 0,37 & 0,23 & 0,56 & 0,87 & 0,88 & 0,11 & 0,78 \\
\hline $\begin{array}{l}\text { Megpróbál mindenben } \\
\text { ellenőrizni }\end{array}$ & 0,00 & 0,00 & 0,00 & 0,01 & 0,01 & 0,06 & 0,00 & 0,12 \\
\hline $\begin{array}{l}\text { Úgy bánik velem, mint } \\
\text { egy kisgyerekkel }\end{array}$ & 0,00 & 0,02 & 0,04 & 0,97 & 0,32 & 0,16 & 0,79 & 0,41 \\
\hline $\begin{array}{l}\text { Meg tud vigasztalni, ha } \\
\text { valami bánt }\end{array}$ & 0,00 & 0,00 & 0,00 & 0,01 & 0,00 & 0,00 & 0,00 & 0,00 \\
\hline $\begin{array}{l}\text { Biztat, hogy tanuljak } \\
\text { rendesen }\end{array}$ & 0,00 & 0,00 & 0,00 & 0,00 & 0,00 & 0,00 & 0,00 & 0,00 \\
\hline $\begin{array}{l}\text { Nem hiszi, hogy van ér- } \\
\text { telme tanulnom }\end{array}$ & 0,36 & 0,18 & 0,02 & 0,00 & 0,04 & 0,00 & 0,23 & 0,00 \\
\hline
\end{tabular}

1. táblázat. Szülői bizalmi/támogatói kapcsolat.

\section{Összegzés}

Összegzésképpen a kutatási eredmények rávilágítanak arra, hogy a családi kapcsolatok jellemzői milyen hatást gyakorolnak a fiatalok rizikómagatartására. Ahhoz, hogy a valósághoz jobban illeszkedő képet kapjunk bemutatom a fiatalok baráti körének rizikómagatartását. Tapasztalatok szerint a baráti kör egészségkárosító szokásairól nyíltabban beszélnek, mint a megkérdezett fiatalok az önbevallott rizikómagatartása helyett.

Statisztikailag releváns összefüggést láthatunk a fiatalok káros szenvedélyeik és a szüleikkel való kapcsolatának minőségi jellemzői (szülőkkel való megbeszélés minősége, szülői monitoring, bizalomteli/támogató kapcsolat) között. Látható, ha a fiatal úgy érzi, nehezen tudja megbeszélni a szüleivel (nevelőszüleivel) az őt foglalkoztató 
problémákat, akkor a fiatal baráti „többsége” fogyaszt szeszesitalt, ez közel 20\%-ot jelent. Ezt az értéket figyelve látható továbbá, ha a fiatal úgy érzi, nagyon könnyen meg tudja beszélni a gondokat a szüleivel (nevelőszüleivel), akkor ez 12\%-os arányt jelent. A szakellátásban nevelkedett fiatal, ha azt érzi, nem tudja megosztani a problémáját valamely gondozójával, akkor baráti társaság „többségét” tekintve 27,9\% fogyaszt alkoholt, ha pedig könnyedén megtudja beszélni, ez az arány lecsökken 6,8\%ra. Látható, hogy a megbeszélés könnyedsége vagy éppen nehézsége milyen hatással lehet a fiatal egészségmagatartására.

Az eredmények rámutatnak, hogy a szülői monitoring hogyan befolyásolja a fiatal egészségmagatartását. Ha a megkérdezett fiatal úgy érzi, hogy az édesanyja nem tud róla semmit, akkor a barátok „,öbbsége” lesz részeg hetente egyszer vagy többször, míg a sokat tud kategóriában 35\%-nak a barátok „többsége” lesz részeg hetente egyszer vagy többször. Ahol az anyai monitoring gyenge, jól látható, hogy azoknak a fiataloknak a baráti „,többségük” használ kábítószert, ez közel 40\% barátot jelent. Viszont sokat tud kategóriában 33\%-nak a barátjának a „többsége” használ kábítószert.

A család a fiatal számára pozitív válasz esetén olyan támaszt jelent, amely megvédheti azoktól a rizikófaktoroktól, amelyek a mai fiatalság jelentős részét veszélybe sodorják.

\section{Irodalomjegyzék}

1. Bauer Béla, Komássy Áron (2008): Új Ifjúsági Szemle VI. évf. 1. szám. Új Mandátum Kiadó, Budapest.

2. Fábián G., Szoboszlai K., Hüse L. [szerk.] (2017): A társadalmi periférián élő gyermekek és fiatalok rizikómagatartásának háttere. Periféria Egyesület, Nyíregyháza. ISBN 978-963-12-9150-6

3. Horváth Cintia (2017): A fiatalok rizikómagatartására vonatkozó hazai nagymintás kutatások eredményeinek áttekintése. In: Fábián G., Szoboszlai K., Hüse L. [szerk.]: A társadalmi periférián élő gyermekek és fiatalok rizikómagatartásának háttere. Periféria Egyesület, Nyíregyháza. 47-59

4. Hüse Lajos, Huszti Éva, Takács Péter (2016): A gyermekvédelem peremén Negatív életesemények hatása a kamaszok és fiatalok egészségkárosító magatartására. Metszetek Vol. 5. No. 4: 80 -108. DOI 10.18392/METSZ/2016/4/5

5. Murányi István, Horváth Rita, Hüse Lajos (2008): Nyíregyházi fiatalok drogfogyasztásának és szubjektív jóllétének jellemzői. A Vörös Postakocsi IV/4: 41-49.

6. Pénzes Mariann, Hüse Lajos, Huszti Éva, Horváth Réka (2007): A nyíregyházi serdülök egészségmagatartása. NyírKEF, Nyíregyháza.

7. Rácz József (1995): Drogfogyasztók kortárs kapcsolatainak elemzése: A szociálpszichológiai és az etnográfiai perspektíva. Psychiátria Hungarica, A Magyar Pszichiátriai Társaság tudományos folyóirata. X/4 377-387. 